\title{
Motivations for Recreating on Farmlands, Private Forests, and State or National Parks
}

\author{
Sandra Sotomayor • Carla Barbieri • \\ Sonja Wilhelm Stanis • Francisco X. Aguilar • \\ Jordan W. Smith
}

Received: 17 April 2013/Accepted: 15 April 2014/Published online: 7 May 2014

(C) Springer Science+Business Media New York 2014

\begin{abstract}
This study explores the importance of different motivations to visit three types of recreational settingsfarms, private forests, and state or national parks. Data were collected via a mail-back questionnaire administered to a stratified random sample of households in Missouri (USA). Descriptive and inferential statistics reveal both similarities and discontinuities in motivations for visiting farms, private forests, and state or national parks for recreation. Being with family, viewing natural scenery, and enjoying the smells and sounds of nature were all highly important motivations for visiting the three types of
\end{abstract}

\author{
S. Sotomayor \\ Tourism Management Department, Universidad San Ignacio de \\ Loyola, Av. La Fontana 550, Lima 12, Peru \\ e-mail: ssotomayor@usil.edu.pe \\ C. Barbieri $(\bowtie)$ \\ Department of Parks, Recreation and Tourism Management, \\ North Carolina State University, 3028D Biltmore Hall, Raleigh, \\ NC 27695, USA \\ e-mail: carla_barbieri@ncsu.edu \\ S. Wilhelm Stanis \\ Department of Parks, Recreation and Tourism, University of \\ Missouri, 105 Anheuser-Busch Natural Resources Bldg., \\ Columbia, MO 65211, USA \\ e-mail: sonjaws@missouri.edu

\section{F. X. Aguilar} \\ Department of Forestry, University of Missouri, 203 Anheuser- \\ Busch Natural Resources Bldg., Columbia, MO 65211, USA \\ e-mail: aguilarf@missouri.edu

\section{J. W. Smith} \\ Digital Imagery Visualization Laboratory, North Carolina State \\ University, 5112 Jordan Hall, Campus Box 7106, Raleigh, \\ NC 27603, USA \\ e-mail: jwsmit12@ncsu.edu
}

settings. However, all 15 motivations examined were perceived to be significantly more important for visits to state or national parks than to farms or private forests. Findings suggest that individuals are more strongly motivated to recreate at state and national parks relative to farmlands or forests. Post hoc paired $t$ tests comparing motivations between both agricultural settings (farms and private forests) revealed significant differences in eight different recreational motivations. Individuals tended to place more importance on the ability to use equipment and test their skills when considering recreating on private forests. Conversely, social motivations (e.g., doing something with the family) were more important when individuals were considering recreating on farmland. Collectively, the findings suggest individuals expect distinctly different outcomes from their visits to farmlands, private forests, or state or national parks. Consequently, all three types of recreational settings have competitive advantages that their managers could capitalize on when making decisions about how to attract new visitors or produce the most desirable experiences for current recreationists.

Keywords Agritourism - Farms - Motivations - Private forests $\cdot$ Recreation experience preference

\section{Introduction}

Fluctuations in agricultural income and the need to preserve land and natural resources for future generations have placed increased pressure on farm and forest landowners across the United States of America (USA) to diversify their cash-flow portfolio and to ensure sustainable revenue generation. As a result, many farm and forest landowners are offering recreational activities to increase the sales of 
their more traditional products (e.g., crops, timber) and to generate revenues directly associated with recreational and tourism activities (Barry and Hellerstein 2004; McGehee 2007; Barbieri and Mahoney 2009; Bernath and Roschewitz 2008; Karppinen 1998; Tew and Barbieri 2012). The substantial growth in the offer of recreational activities in agricultural settings evidenced during the last decade (USDA: NASS 2009) has been coupled with an increased interest for recreating on farms and private forests among the general population (Cordell 2008). By opening their gates to the public and offering organized recreational, leisure, and educational activities, farms and private forests offer a "countryside experience" to the public — an experience largely romanticized by a lifestyle that contrasts to the hustle of urban settings (Nilsson 2002).

Although research on outdoor recreation in public settings is abundant, few studies have investigated the motivations for visiting private agricultural settings, both farms and forests. This gap in the literature is notable given that $91 \%$ of land in the continental USA is either cropland, pasture, or forest (Walls et al. 2009), much of which is suitable for recreation (Cordell 2004; Smith et al. 2003). Previous research on recreation on agricultural settings has almost exclusively focused on the supply side of the market, with most studies concentrating on landowners' entrepreneurial motivations (Nickerson et al. 2001; Ollenburg and Buckley 2007; Tew and Barbieri 2012). Few studies have focused on the demand side, and only one study (Jolly and Reynolds, 2005) specifically focused on public's motivations for recreating on farms and private forests. Moreover, existing studies have predominantly focused on private farmers and excluded private forest owners.

This investigation responds to the need for more scholarship focused on the demand for recreational opportunities provided by farms and private forests, and how recreation experiences in these agricultural settings differ from more traditional natural sites such as state and national parks. Examining two types of private agricultural settings, farms and forests, is important given the domination of farms in the agritourism literature and the scarcity of studies focused on recreational opportunities provided by private forests. Comparing individuals' motivations for recreating on farms and private forests relative to state and national parks allows us to recognize if individuals desire different outcomes from recreational activities they pursue in distinctly different settings. Such information is useful to private landowners and resource managers, especially agritourism operators, interested in the comparability or substitutability of recreational opportunities offered at different settings (Graefe et al. 2010).

We utilize recreational opportunities provided at state and national parks as a contrast to those offered at agricultural settings, given their wide recognition in the USA as traditional and highly desirable recreational settings. While the recreational opportunities provided by state and national parks are by no means homogeneous, previous studies have revealed that these typical naturebased recreational areas facilitate the achievement of common sets of desired outcomes (Pierskalla et al. 2004; Weber and Anderson 2010). For example, a meta-analysis of surveys administered to visitors to nine different state parks and natural areas across the USA revealed only one potential motivation ("To learn more about natural history in the area") that differed significantly across study areas (Pierskalla et al. 2004). An additional motivation for using state and national parks as a comparison group is that their visitors' motivations have been extensively studied and have been foundational in developing universal sets of potential motivations for participation in outdoor recreation (Driver 1976, 1996, 2008).

Study results can serve private landowners interested in diversifying their portfolio through recreation to develop targeted marketing materials and to guide a variety of planning and management tasks, such as measuring recreation supply and demand, developing management objectives, and preventing or managing user conflicts (Graefe et al. 2000; Thapa et al. 2004). Delivering services based on visitors' needs can provide better recreational experiences (Beh and Bruyere 2007), thus optimizing visitor satisfaction (Graefe et al. 2000). Study results can also help to shape policies and management strategies designed to maintain and/or expand the recreation opportunities offered by farms and private forests (McCool and Reilly 1993; Kemperman and Timmermans 2006). It has been suggested that maintaining these opportunities is essential to ensure the sustainable production of distinct types of ecosystem services such as an ability to preserve cultural heritage and informal educational opportunities (Daniel et al. 2012).

\section{Related Literature}

Agritourism: Visiting Farms and Private Forests for Recreation

Agritourism occurs when visiting a working agricultural setting for recreation or educational purposes (Gil Arroyo et al. 2013). Although many definitions explicitly refer to the "farm" as the setting for agritourism (e.g., Barbieri and Mshenga 2008; Clarke 1999; McGehee 2007; Ollenburg and Buckley 2007), some studies expand its definition to include activities occurring in any agricultural estate (Barbieri and Mahoney 2009; Che et al. 2005; Lobo 2001; Marques 2006; Tew and Barbieri 2012) or within the 
agrarian environment (Sharpley and Sharpley 1997). In the USA, forestlands are classified as an agricultural setting because of their central role in supplying sawtimber for commercial markets. The USDA Forest Service, which is the primary agency tasked with managing federal forestlands, manages 78 million hectares of designated national forests and grasslands throughout the country (USDA Forest Service 2012). Likewise, private forestlands in the USA have traditionally played an important role in supplying sawtimber, pulpwood, and raw materials for biofuels production to markets (Newman and Wear 1993). As an alternative to managing private forestlands for these traditional commodity outputs, a large proportion of landowners manage their forests primarily for esthetic, privacy, legacy, and recreation purposes (Butler and Leatherberry 2004). Given private forests can be, and are, managed for recreational use, we consider them a unique component of the portfolio of agritourism settings. Private forests are often overlooked in agritourism studies in spite of them being considered "agricultural" settings. Taking into consideration the existing definitional ambiguity related to the setting, when referring to agritourism, this study includes farms and private forests.

Agritourism is usually developed as a means of entrepreneurial diversification to compensate for lower agricultural prices originated by large-scale commodity production, reduced government support, and market changes, as well as to accomplish a variety of entrepreneurial goals (Barbieri et al. 2008; Che et al. 2005; Nickerson et al. 2001; Tew and Barbieri 2012; Veeck et al. 2006). Thus, agritourism is another consumptive use of the landscape that may help to preserve farms and forested lands (Che et al. 2005; McGehee and Kim 2004). Agritourism encompasses a wide variety of activities including, but not limited to, recreational self-harvest (e.g., pick-your own apples and mushroom gathering), hay rides, corn mazes, hunting, hiking, and bird watching. The most commonly cited activities in North America are tours and special events (Barbieri et al. 2008), while accommodation services and self-catering activities conducive to nature and cultural appreciation seem to be most prevalent in Europe (Ilbery et al. 1998; Nilsson 2002). Specific to Missouri, the geographic extent to which the present study is focused, Tew and Barbieri (2012) report the most common activities offered by farms engaged in agritourism are tours (50\%), recreational self-harvest or u-pick-up activities (38\%), and observation/participation in agricultural processes $(35 \%)$. Common recreational activities in forests are hiking and nature observation including bird watching and the appreciation of the scenery (Cordell 2008). Although specific information is not available on recreational activities in private forests (Cordell et al. 1990), Teasley et al. (1999) report that $48 \%$ of private landowners in the USA allow persons outside their family to access their lands for recreation. Among them, the most common recreational activities reported were hunting of small $(65 \%)$ and large $(55 \%)$ animals, followed by hiking (35\%) and fishing (32\%).

\section{Motivations for Visiting Natural Settings}

Motivations are the underlying forces or internal factors (e.g., a purpose or a desire) that arouse and direct human behaviors (Iso-Ahola 1999). Although natural environments seem to provide humans with a variety of desired psychological, social, and physiological outcomes, investigators have not agreed upon the origins of individuals' recreational preferences for those natural environments (Kyle et al. 2004). Numerous studies have explored people's motivations as determinants of the decision making process for visiting a recreational setting (Graefe et al. 2000; Jackson 2005; Kyle et al. 2004, 2006; Thapa et al. 2004). The overall enjoyment of nature and escaping personal/social pressures are the strongest motivations for engaging in nature-based recreation (Anderson et al. 2008; Beh and Bruyere 2007; Geide et al. 2008; Graefe et al. 2000; Hall et al. 2010; Kyle et al. 2004, 2006; Stein et al. 2003). However, the literature related to agritourists motivations is limited. Jolly and Reynolds (2005) found that purchasing fresh/homemade products, purchasing directly from farmers, experiencing nature, and vacation/ relaxation were the most prevalent motivations for visiting a farm or ranch among potential agritourists in two counties located in central California (USA).

Motivations have also been examined relative to other constructs. For example, Devesa et al. (2010) found that motivations among visitors to Spain were associated with their overall experience and satisfaction levels. Other studies have examined visitor motivations to explain place attachment (Halpenny 2006; Kyle et al. 2004; McEwen 2010), enduring involvement (Chen 2008; Kyle et al. 2006; Ritchie et al. 2010), environmental attitudes (Kim et al. 2006; Luo and Deng 2008; Smith 2008), wilderness involvement (Hall et al. 2010), and learning experiences (Packer and Ballantyne 2002; Stein et al. 2003), among others.

The examination of motivations within recreation and tourism has served several practical purposes, specifically to develop market segmentations of potential and current visitors (Devesa et al. 2010; Geide et al. 2008; Hall et al. 2010; Park and Yoon 2009). For example, Park and Yoon (2009) developed a motivation-based segmentation of the tourism market in the Korean countryside, identifying four distinct visitor segments: (1) those seeking family togetherness; (2) passive tourists mostly searching for sports and games as leisure activities; (3) those seeking a variety of 
experiences; and (4) those mostly in search of learning and excitement. Similarly, Beh and Bruyere (2007) identified and profiled three visitor segments (Escapists, Learners, and Spiritualists) by clustering visitors based on their motivations to visit three national reserves in north central Kenya.

Fewer studies have examined motivations across different natural settings. Yuan and McEwen (1989) investigated differences across campers' experience preferences in three campground settings that differed in their classification along the recreation opportunity spectrum; they concluded that visitors' preferences differed less than expected across setting classifications and that camping motivations, regardless of setting type, were fairly homogenous across visitors. When examining the relationship between activities, settings, and experience preferences among visitors to several sites within the Delaware State Park System, Vogelsong et al. (1998) found that visitors' motivations, while varying significantly statistically, were not substantially different across the four setting types identified (historic, suburban, pond, and seashore). In a similar vein, Pierskalla et al. (2004) conducted a meta-analysis of nine studies querying visitors to state parks and other nature-based recreation settings about their motivations for visiting the setting. The analyses revealed that only one motivation (the desire to learn more about natural history of the area) varied significantly across the nine study settings.

More recent and generalizable results were found in Graefe et al.'s (2010) study utilizing data collected from the National Survey on Recreation and the Environment, a nationwide general population survey. After analyzing 13 motivations for participating in sightseeing, hiking, camping, and walking in distinct natural settings (coastal waters, inland freshwaters, forests, grasslands, (sub)urban parks, deserts, and mountains), they found weak and inconsistent variation in motivations across the settings for each of the activities examined. Of the 52 activity-motivation pairs examined, only nine exhibited statistically significant variation across setting type. Moreover, Graefe and his colleagues found "the motivations with the highest mean importance scores were similar across all study activities" (262), and included to be with family, to be outdoors, to get away from the demands of life, to experience nature, and to get physical exercise.

Collectively, these previous investigations suggest little variation in recreation motivations relative to setting type. These results, however, are far from conclusive as they have all focused on nature-based recreation settings such as publicly managed recreation areas, state parks, and wilderness areas. Very few studies have attempted to discern variations in recreation motivations relative to setting types that are outside the commonly conceptualized nature-based recreation areas. Weber and Anderson's (2010) study of motivations across urban and non-urban settings in Australia is a notable example. It should also be noted that several social scientists have argued examinations of the motivation-setting relationship should include variables that might confound the relationship such as individuals' distance to the resource area (Anderson et al. 2008) and the specific types of activities facilitated by particular settings (Anderson and Fulton 2008). Our investigation will expand upon the previous set of findings by specifically examining individuals' motivations for visiting farms and private forests. To our knowledge, no study has been conducted to examine visitors' motivations across different agricultural settings, or to compare those to visiting more traditional nature-based recreation settings (e.g., state and national parks).

In sum, although there is a growing trend of agritourism in the USA, in both the number of providers and the number of visitors, still little is known about this relatively new form of recreation. In particular, more information is needed from the demand side, to understand the motivations and needs of potential and current visitors to farms and private forests, especially to understand whether visit motivations vary across different types of settings.

\section{Data and Methods}

\section{Data Collection}

The purpose of this study was to explore the desired experiences of current and potential visitors, and to compare the importance of each potential motivation across setting types. Data required to address this objective were collected via a self-administered mail-back questionnaire administered to adults living in Missouri, USA. The sampling frame consisted of all adult residents living within the state, estimated at $4.56 \mathrm{M}$ in the 2010 Census (U.S. Census Bureau 2011). A random sample of 5,000 households was drawn relative to metropolitan $(n=3,500)$ and nonmetropolitan $(n=1,500)$ county-level designations (USDA: ERS 2004). The eight-page questionnaire, which solicited responses regarding individuals' motivations for visiting working farms, private forests, and state and national parks, was mailed following a modified version of the Tailored Design Method (Dillman et al. 2009).

\section{Measures: The Recreation Experience Preference} (REP) Scales

Most research on visitor motivations in outdoor recreation builds on Driver's (1983) conceptual typology and measurement instruments designed to gage specific motivations 
for outdoor recreation participation (Graefe et al. 2000; Kyle et al. 2004, 2006; Walker et al. 2001). The instruments referred to as the REP scales are composed of over 300 statement items (i.e., possible motivations) organized within 21 domains (e.g., achievement/stimulation, risk taking, family togetherness, learning, and enjoying nature). Collectively, the items are designed to capture psychological, social, and perceived physiological outcomes that can be obtained through participation in outdoor recreation (Graefe et al. 2010; Kyle et al. 2004; Manfredo et al. 1996). The REP scales have been tested for validity across multiple studies and have proven to be a reliable and consistent indicator of motivations for recreation experiences (e.g., Hall et al. 2010; Manfredo et al. 1996).

The REP scales are not usually used in their full extent. Rather, researchers typically employ smaller versions by selecting sets of items or certain domains pertinent to their research interest and focus (Graefe et al. 2000; Thapa et al. 2004). In the present study, we selected 15 potential desired outcomes (motivations) that could be achieved from recreating on a farm, in a private forest, or in a state or national park. Individuals were asked to indicate how important each desired outcome was when considering visiting each of the three recreational settings. Responses were measured with a 5-point Likert scale, which ranged from very unimportant (1) to very important (5). ${ }^{1}$

To facilitate responses, respondents were provided with the following definitions prior to responding to the REP statement items: (1) Agritourism farms provide recreational activities for visitors besides agriculture production. Typical agritourism activities include pick-your own apples, hayrides, corn mazes, etc. (2) Private forests are managed by individuals or organizations and not state or federal government. Many of them are opened to the public for recreational use, such as for hunting, hiking, bird watching, etc. (3) State and National Parks are large land or water areas set to protect natural resources and to provide recreational opportunities for visitors, such as camping, fishing, boating, biking, etc.

Participants were also asked about their outdoor recreation preferences in terms of their past visitation, the types of recreational activities they engage in, and their willingness to visit an agritourism farm, a private forest, or a state or national park in the future. The questionnaire also solicited information regarding socio-economic (e.g., age, gender, household income, level of education, and employment status), lifestyle (e.g., engagement in recreational activities),

\footnotetext{
${ }_{1}^{1}$ Identical wording was used to solicit motivations for visiting the three types of settings except for one item: slightly different wording was used to assess "Share your outdoor skills with others," where "outdoor" was replaced with "agritourism" when inquired about visiting agritourism farms.
}

and residential (e.g., residence distance from a 50,000 pop. area) characteristics.

\section{Analysis}

Analysis involved descriptive and inferential analysis. Descriptive analyses were performed to examine respondents' socio-economic characteristics and their motivations for outdoor recreation participation. A series of Repeated Measures Analysis of Variance (RM-ANOVA) were conducted to compare the 15 visitation motivations across the three setting types (farms, private forests, state or national parks). Mauchly's test was conducted to validate similar variances in each motivation across different settings (i.e., assumption of sphericity), and pertinent correction measures were applied when applicable (Howell 2013). Given that listwise method was used to handle missing values when comparing motivations across the three natural settings, initial mean scores within each setting may slightly differ from those resulting from the RM-ANOVAs conducted. Finally, post hoc paired $t$ tests were conducted to compare all pairs of levels of the independent variable in each significant RM-ANOVA results. The Bonferroni correction $(0.05 / 3=p<0.017)$ was used to reduce type II statistical error.

\section{Results}

A total of 969 questionnaires were returned completed, yielding a $19.6 \%$ adjusted response rate after accounting for undeliverable addresses. The response rate falls within ranges in similar studies (Jolly and Reynolds 2005; Gursoy et al. 2010; Huh and Vogt 2008). Respondents represent the metropolitan $(67.3 \%)$ and non-metropolitan $(32.3 \%)$ distribution of Missouri as drew for this study (70 and $30 \%$, respectively), as well as 102 counties (out of 114) in the state. Non-response bias was evaluated by comparing mean values of key socio-economic variables across mailings (Armstrong and Overton 1977). Independent $t$ and $\chi^{2}$ tests $(p<0.001)$ showed no significant differences on the age $(t=-0.128 ; p=0.898)$, gender $\left(\chi^{2}=4.557\right.$; $p=0.036)$, residence location $\left(\chi^{2}=4.294 ; p=0.508\right)$, and income $\left(\chi^{2}=9.283 ; p=0.233\right)$ between first and second wave respondents.

\section{Socio-economic Profile and Visitation Preferences}

The gender of respondents was nearly evenly divided (51.6\% males; Table 1). A fifth $(21.0 \%)$ of respondents were between 18 and 40-years old, $44.0 \%$ were between 41 and 60-years old, and $35.0 \%$ were at least 61-years old. On average, respondents were 53.9-years old $(\mathrm{SD}=15.5)$. 
Table 1 Gender, age, education level, annual income, and employment status of respondents

\begin{tabular}{|c|c|c|}
\hline & $n$ & $\%$ \\
\hline \multicolumn{3}{|l|}{ Gender $(n=954)$} \\
\hline Male & 492 & 51.6 \\
\hline Female & 462 & 48.4 \\
\hline \multicolumn{3}{|l|}{ Age $(n=960)$} \\
\hline $18-30$ years old & 81 & 8.4 \\
\hline $31-40$ years old & 121 & 12.6 \\
\hline $41-50$ years old & 186 & 19.4 \\
\hline $51-60$ years old & 236 & 24.6 \\
\hline $61-70$ years old & 201 & 20.9 \\
\hline 71 years old or older & 135 & 14.1 \\
\hline Mean & & $(53.9)$ \\
\hline Standard deviation & & $(15.5)$ \\
\hline \multicolumn{3}{|c|}{ Highest level of education $(n=945)^{\mathrm{a}}$} \\
\hline High school graduate & 274 & 29.0 \\
\hline Some college & 210 & 22.2 \\
\hline 2-year college degree & 108 & 11.4 \\
\hline 4-year college degree & 192 & 20.3 \\
\hline Post-graduate studies & 161 & 17.0 \\
\hline Mean & & (2.7) \\
\hline Standard deviation & & (1.5) \\
\hline \multicolumn{3}{|c|}{ Annual household income before Taxes $(n=895)^{\mathrm{b}}$} \\
\hline Less than $\$ 25,000$ & 160 & 17.9 \\
\hline$\$ 25,000-\$ 34,999$ & 150 & 16.8 \\
\hline$\$ 35,000-\$ 49,999$ & 171 & 19.1 \\
\hline$\$ 50,000-\$ 74,999$ & 165 & 18.4 \\
\hline$\$ 75,000-\$ 99,999$ & 104 & 11.6 \\
\hline$\$ 100,000-\$ 149,999$ & 100 & 11.2 \\
\hline$\$ 150,000$ or more & 45 & 5.1 \\
\hline Mean & & (3.4) \\
\hline Standard deviation & & $(1.8)$ \\
\hline \multicolumn{3}{|c|}{ Respondents employment status $(n=950)^{\mathrm{c}}$} \\
\hline Full-time employee & 468 & 49.3 \\
\hline Part-time employee & 93 & 9.8 \\
\hline Retired & 286 & 30.1 \\
\hline Homemaker & 102 & 10.7 \\
\hline Student & 34 & 3.6 \\
\hline Unemployed & 64 & 6.7 \\
\hline
\end{tabular}

${ }^{a}$ Measured on a five-point scale ranging from 1 (High school graduate) to 5 (Post-graduate studies)

b Measured on a eight-point scale ranging from 1 (Less than \$25,000) to $8(\$ 200,000$ or more $)$

c Percentages sum to more than $100 \%$, as respondents were able to select multiple categories

Over one-quarter $(29.0 \%)$ of respondents were high school graduates, and one-third (33.6\%) had some college studies or a 2-year college degree. Over one-third (37.3\%) of respondents had a four-year college or higher degree. A
Table 2 Past visitation, type of activities engaged during visit and willingness to visit an agritourism farm, a private forest, and a state/ National park in the future

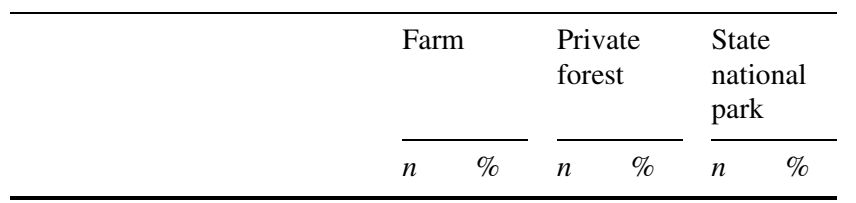

Past visitation for recreation purposes

$\begin{array}{lllllll}\text { Did visit } & 433 & 48.1 & 464 & 51.2 & 812 & 86.7 \\ \text { Did not visit } & 467 & 51.9 & 443 & 48.8 & 125 & 13.3\end{array}$

Likeliness to visit in the next 12 months

$\begin{array}{lcccccr}\text { Very unlikely } & 116 & 12.3 & 111 & 11.7 & 60 & 6.3 \\ \text { Unlikely } & 152 & 16.1 & 178 & 18.7 & 68 & 7.1 \\ \text { Undecided } & 269 & 28.5 & 235 & 24.7 & 145 & 15.2 \\ \text { Likely } & 294 & 31.1 & 289 & 30.4 & 337 & 35.4 \\ \text { Very likely } & 113 & 12.0 & 137 & 14.4 & 343 & 36.0 \\ \text { Mean }^{\mathrm{a}} & (3.1) & (3.2) & (3.9) \\ \text { Standard deviation } & (1.2) & (1.2) & & (1.2)\end{array}$

Most popular recreational activities ${ }^{\text {b,c }}$

$\begin{array}{lllllll}\text { Attend a festival or event } & 303 & 70.3 & 134 & 28.9 & 307 & 38.1\end{array}$

$\begin{array}{lllllll}\text { Hiking, biking or cross- } & 146 & 33.9 & 269 & 58.1 & 498 & 61.8\end{array}$ country

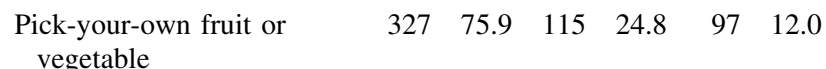

$\begin{array}{lllllll}\text { Wildlife observation } & 166 & 38.5 & 259 & 55.9 & 489 & 60.7\end{array}$

$\begin{array}{llllllll}\text { Boating, canoeing or sailing } & 111 & 25.8 & 173 & 37.4 & 445 & 55.2\end{array}$

$\begin{array}{lllllll}\text { Fishing } & 145 & 33.6 & 237 & 51.2 & 469 & 58.2\end{array}$

Overnight stay (last 5 years) ${ }^{\mathrm{c}}$

$\begin{array}{lllllll}\text { Did not overnight } & 339 & 78.6 & 275 & 59.3 & 417 & 51.5\end{array}$

$\begin{array}{lllllll}\text { Did overnight for free } & 13 & 3.0 & 74 & 15.9 & 68 & 8.4\end{array}$

$\begin{array}{llllllll}\text { Did overnight for a fee } & 77 & 17.9 & 97 & 20.9 & 287 & 35.5\end{array}$

$\begin{array}{lllllll}\text { Did overnight for free and } & 2 & 0.5 & 18 & 3.9 & 37 & 4.6\end{array}$ for a fee

${ }^{a}$ Measured on a five-point scale ranging from 1 (very unlikely) to 5 (very likely)

b Percentages sum to more than $100 \%$, as respondents were able to select multiple categories

c This only includes those who have visited farms ( $n=433 ; 48.1 \%)$, private forests $(n=464 ; 51.2 \%)$ and state/national parks $(n=812$; $86.7 \%)$ in the past

third of respondents $(34.7 \%)$ reported a gross annual household income less than $\$ 35,000 ; 37.5 \%$ reported a household income between $\$ 35,000$ and $\$ 75,000$; and $27.9 \%$ reported incomes of at least $\$ 75,000$. Nearly, onehalf of respondents $(49.3 \%)$ were employed full-time and a third $(30.1 \%)$ were retired. Gender $\left(\chi^{2}=0.27, \mathrm{df}=1\right.$, $p=0.60)$, income $\left(\chi^{2}=5.94, \mathrm{df}=6, p=0.43\right)$, and employment status $\left(\chi^{2}=1.85, \mathrm{df}=2, p=0.40\right)$ of survey respondents were significantly comparable to the general population of Missouri as reported in 2010 US Census and the American Community Survey. However, respondents did tend to be older $\left(\chi^{2}=14.12, \mathrm{df}=5\right.$, 
Table 3 Importance of motivations for visiting a farm for recreation purposes
${ }^{a}$ Measured on a five-point scale ranging from 1 (very unimportant) to 5 (very important)

\begin{tabular}{lclllll}
\hline Motivations & $n$ & $\begin{array}{l}\text { Unimportant } \\
(\%)\end{array}$ & $\begin{array}{l}\text { Neutral } \\
(\%)\end{array}$ & $\begin{array}{l}\text { Important } \\
(\%)\end{array}$ & $M^{\mathrm{a}}$ & SD \\
\hline Do something with their family & 935 & 4.4 & 8.8 & 86.8 & 4.26 & 0.90 \\
View the scenic beauty & 949 & 3.6 & 7.2 & 89.2 & 4.24 & 0.81 \\
Enjoy the smells and sounds of nature & 952 & 4.5 & 11.4 & 84.1 & 4.05 & 0.82 \\
Learn more about nature & 952 & 5.0 & 15.1 & 79.9 & 3.98 & 0.87 \\
Experience new and different things & 949 & 5.3 & 13.4 & 81.3 & 3.96 & 0.84 \\
Have a change from their daily routine & 949 & 5.3 & 18.3 & 76.4 & 3.88 & 0.83 \\
Get exercise & 944 & 6.7 & 21.6 & 71.7 & 3.83 & 0.89 \\
Give their mind a rest & 950 & 10.9 & 27.5 & 61.6 & 3.69 & 0.99 \\
Experience excitement & 935 & 10.3 & 26.4 & 63.3 & 3.68 & 0.98 \\
Use their equipment & 933 & 13.1 & 26.5 & 60.4 & 3.63 & 1.04 \\
Experience solitude & 945 & 12.9 & 31.2 & 55.9 & 3.58 & 1.01 \\
Recall good times from the past & 948 & 12.0 & 29.6 & 58.4 & 3.58 & 0.98 \\
Be with people having similar values & 940 & 14.1 & 34.5 & 51.4 & 3.46 & 0.99 \\
Think about their personal values & 946 & 14.6 & 37.8 & 47.6 & 3.42 & 0.99 \\
Share their agritourism skills & 941 & 23.4 & 47.5 & 29.1 & 3.06 & 0.98 \\
\hline
\end{tabular}

$p=0.01)$ and more educated $\left(\chi^{2}=15.17, \mathrm{df}=4\right.$, $p<0.01)$ than the state's general population.

Regarding recreation visitation, roughly one-half of respondents had visited a farm $(48.1 \%)$ or a private forest $(51.2 \%)$ for recreation at least once in their lives, which is a much lower proportion than those who have visited a state or national park (86.7 \%; Table 2). These results reflect the recent development of agritourism in the USA and support the common assumption that state and national parks offer high quality recreational opportunities throughout the country (Siderelis et al. 2012; Walls et al. 2009). A majority of respondents $(71.4 \%)$ were either likely or very likely to visit a state or national park in the next 12 months. Concurrently, about half of respondents indicated that they were either likely or very likely to visit either a private forest $(44.8 \%)$ or an agritourism farm $(43.1 \%)$ in the next 12 months. These findings highlight the potential for the development of agritourism in Missouri and suggest that the increasing trend in agritourism nationwide is occurring in the state of Missouri as well (Cordell 2008).

The most popular activities engaged in when visiting each of the three recreational settings were those strongly linked to the setting's specific offerings. The most frequent activities participated in when visiting a farm were "pickyour-own fruit or vegetable" (75.9\%), "attend a festival or event" (70.3\%), and "wildlife observation" (38.5\%). The most popular activities when visiting both a private forest and state or national parks were "hiking, biking or crosscountry" (58.1 and $61.8 \%$, respectively), "wildlife observation" (55.9 and $60.7 \%$, respectively), and "fishing" (51.2 and $58.2 \%$, respectively). Across all three settings, the use of accommodation services was low. Most respondents had not stayed overnight in farms (78.6\%), private forests $(59.3 \%)$, or even state or national parks $(51.5 \%)$ during the last 5 years. These values for activity participation and use of accommodation services found here are similar to those reported from samples of the entire US population (Cordell 2004, 2008).

Motivations for Visiting Farms, Private Forests,
and State or National Parks

A majority of respondents stated that doing something with their family $(86.8 \%)$, viewing the scenic beauty $(89.2 \%)$, and enjoying the smells and sounds of nature $(84.1 \%)$ were important or very important motivations for visiting a farm for recreational purposes (Table 3). In contrast, most respondents considered that thinking about their personal values $(52.4 \%)$ and sharing their agritourism skills (70.9\%) were less than important motivations for visiting farms.

Further analyses showed similar results regarding motivations associated with visiting private forests. Viewing the scenic beauty $(91.5 \%)$, doing something with their family $(84.0 \%)$, and enjoying the smells and sounds of nature $(86.1 \%)$ were reported as being important motivations for visiting a private forest (Table 4). Sharing their outdoor skills with others was not an important motivation to visit a private forest for most $(57.0 \%)$ respondents.

Almost all the motivations examined appeared as important drivers for visiting a state or national park. On average, the most important motivations were viewing the scenic beauty and doing something with their family; 93.6 
Table 4 Importance of motivations for visiting a private forest for recreation purposes
${ }^{\text {a }}$ Measured on a five-point scale ranging from 1 (very unimportant) to 5 (very important)

Table 5 Importance of motivations for visiting a state/national park

\footnotetext{
${ }^{a}$ Measured on a five-point scale ranging from 1 (very unimportant) to 5 (very important)
}

\begin{tabular}{lclllll}
\hline Motivations & $n$ & $\begin{array}{l}\text { Unimportant } \\
(\%)\end{array}$ & $\begin{array}{l}\text { Neutral } \\
(\%)\end{array}$ & $\begin{array}{l}\text { Important } \\
(\%)\end{array}$ & $M^{\mathrm{a}}$ & SD \\
\hline View the scenic beauty & 926 & 2.7 & 5.8 & 91.5 & 4.26 & 0.78 \\
Do something with their family & 919 & 4.5 & 11.5 & 84.0 & 4.11 & 0.88 \\
Enjoy the smells and sounds of nature & 927 & 3.9 & 10.0 & 86.1 & 4.11 & 0.84 \\
Learn more about nature & 925 & 4.5 & 15.0 & 80.5 & 3.97 & 0.85 \\
Have a change from their daily & 924 & 4.0 & 13.6 & 82.4 & 3.97 & 0.78 \\
routine & & & & & & \\
Get exercise & 916 & 5.9 & 18.4 & 75.7 & 3.89 & 0.87 \\
Experience new and different things & 924 & 5.0 & 18.0 & 77.0 & 3.87 & 0.83 \\
Give their mind a rest & 924 & 8.4 & 22.2 & 69.4 & 3.79 & 0.94 \\
Use their equipment & 923 & 9.4 & 21.2 & 69.4 & 3.78 & 1.00 \\
Experience solitude & 921 & 9.4 & 27.3 & 63.3 & 3.72 & 0.98 \\
Experience excitement & 919 & 10.0 & 30.1 & 59.9 & 3.62 & 0.95 \\
Recall good time from the past & 924 & 11.6 & 28.9 & 59.5 & 3.60 & 0.98 \\
Think about their personal values & 919 & 12.1 & 37.2 & 50.7 & 3.47 & 0.97 \\
Be with people having similar values & 917 & 13.7 & 34.6 & 51.7 & 3.45 & 0.98 \\
Share their outdoor skills & 923 & 16.4 & 40.6 & 43.0 & 3.32 & 0.99 \\
\hline
\end{tabular}

\begin{tabular}{lcccccc}
\hline Motivations & $n$ & $\begin{array}{l}\text { Unimportant } \\
(\%)\end{array}$ & $\begin{array}{l}\text { Neutral } \\
(\%)\end{array}$ & $\begin{array}{l}\text { Important } \\
(\%)\end{array}$ & $M^{\mathrm{a}}$ & SD \\
\hline View the scenic beauty & 942 & 1.8 & 4.6 & 93.6 & 4.41 & 0.72 \\
Do something with their family & 935 & 2.7 & 6.3 & 91.0 & 4.35 & 0.80 \\
Enjoy the smells and sounds of nature & 942 & 3.0 & 9.2 & 87.8 & 4.23 & 0.80 \\
Learn more about nature & 944 & 2.8 & 12.3 & 84.9 & 4.13 & 0.80 \\
Have a change from their daily & 940 & 3.0 & 11.1 & 85.9 & 4.11 & 0.78 \\
routine & & & & & & \\
Experience new and different things & 947 & 3.6 & 13.5 & 82.9 & 4.05 & 0.81 \\
Use their equipment & 939 & 6.2 & 15.9 & 77.9 & 4.02 & 0.95 \\
Get exercise & 933 & 5.0 & 15.6 & 79.4 & 4.02 & 0.87 \\
Experience excitement & 936 & 6.3 & 19.3 & 74.4 & 3.94 & 0.93 \\
Give their mind a rest & 939 & 7.7 & 20.8 & 71.5 & 3.89 & 0.96 \\
Experience solitude & 938 & 9.5 & 24.8 & 65.7 & 3.81 & 1.00 \\
Recall good time from the past & 943 & 8.0 & 26.9 & 65.1 & 3.76 & 0.96 \\
Be with people having similar values & 938 & 11.1 & 33.3 & 55.6 & 3.59 & 0.99 \\
Think about their personal values & 935 & 11.1 & 37.5 & 51.4 & 3.55 & 0.99 \\
Share their outdoor skills & 938 & 14.1 & 39.2 & 46.7 & 3.43 & 1.00 \\
\hline
\end{tabular}

and $91.0 \%$ of respondents indicated that these motivations were important (Table 5). Enjoying the smells and sounds of nature, learning more about nature, and having a change from a daily routine were all, on average, strong motivations for visiting a state or national park. The least important motivation for visiting a state or national park was sharing outdoor skills.

In sum, respondents reported a variety of motivations as important to visit farms, private forests, and state or national parks for recreation. Overall, the three most important motivations for visiting all three settings, with slight differences on the rankings among settings, were doing something with their family, viewing the scenic beauty, and enjoying the smells and sounds of nature. These results align with previous studies that suggested enjoying and being close to nature were important motivations for engaging in outdoor recreation in different natural settings (e.g., Graefe et al. 2000, 2010). Notably, the least important motivation for visiting all three natural settings was sharing their agricultural/outdoor skills with others, which is consistent with previous findings in other regions in the USA (Stein et al. 2003). 
Table 6 A comparison of importance of motivations for visiting a farm, a private forest, and a state/national park for recreation purposes (Repeated Measures ANOVA)

\begin{tabular}{|c|c|c|c|c|c|c|}
\hline \multirow[t]{2}{*}{ Motivations } & \multicolumn{3}{|c|}{ Importance mean $^{\mathrm{a}}$} & \multirow[t]{2}{*}{$F$} & \multirow[t]{2}{*}{$\mathrm{df}^{\mathrm{b}}$} & \multirow[t]{2}{*}{$p$ value } \\
\hline & Farm & Forest & Park & & & \\
\hline View the scenic beauty & 4.25 & 4.28 & 4.42 & 34.151 & 1.969 & $p<0.001^{\mathrm{c}}$ \\
\hline Do something with their family & 4.28 & 4.12 & 4.36 & 60.090 & 1.987 & $p<0.001^{\mathrm{d}}$ \\
\hline Enjoy the smells and sounds of nature & 4.06 & 4.13 & 4.23 & 31.798 & 1.955 & $p<0.001^{\mathrm{d}}$ \\
\hline Learn more about nature & 3.98 & 3.98 & 4.14 & 26.779 & 1.958 & $p<0.001^{\mathrm{c}}$ \\
\hline Have a change from their daily routine & 3.90 & 3.98 & 4.12 & 47.671 & 1.949 & $p<0.001^{\mathrm{d}}$ \\
\hline Experience new and different things & 3.98 & 3.88 & 4.06 & 26.463 & 1.960 & $p<0.001^{\mathrm{d}}$ \\
\hline Use their equipment & 3.65 & 3.81 & 4.03 & 90.885 & 1.949 & $p<0.001^{\mathrm{d}}$ \\
\hline Get exercise & 3.84 & 3.90 & 4.03 & 34.194 & 1.921 & $p<0.001^{\mathrm{c}}$ \\
\hline Experience excitement & 3.69 & 3.63 & 3.95 & 77.204 & 1.928 & $p<0.001^{\mathrm{c}}$ \\
\hline Give their mind a rest & 3.70 & 3.79 & 3.89 & 27.476 & 1.876 & $p<0.001^{\mathrm{d}}$ \\
\hline Experience solitude & 3.57 & 3.73 & 3.81 & 43.091 & 1.920 & $p<0.001^{\mathrm{d}}$ \\
\hline Recall good times from the past & 3.59 & 3.60 & 3.76 & 32.706 & 1.945 & $p<0.001^{\mathrm{c}}$ \\
\hline Be with people having similar values & 3.49 & 3.46 & 3.59 & 14.306 & 1.921 & $p<0.001^{\mathrm{c}}$ \\
\hline Think about their personal values & 3.43 & 3.47 & 3.55 & 11.498 & 1.888 & $p<0.001^{\mathrm{c}}$ \\
\hline Share their agritourism/outdoor skills & 3.07 & 3.33 & 3.44 & 94.846 & 1.887 & $p<0.001^{\mathrm{d}}$ \\
\hline
\end{tabular}

\section{A Comparison of Motivations Among Agricultural} Settings and State or National Parks

RM-ANOVA showed the importance level of all 15 motivations for visiting natural areas significantly differed whether respondents were to visit a farm, a private forest, or either a state or national park (Table 6). The Bonferroni adjusted paired $t$ tests suggest that all 15 motivations are statistically more important $(p<0.017)$ when visiting a state or national park as compared to either of the agricultural settings. When evaluating motivations across the two types of agricultural settings, pairwise comparisons showed no statistical differences for seven out of the 15 motivations: experiencing excitement, learning more about nature, getting exercise, being with people having similar values, thinking about personal values, recalling good times from the past, and viewing scenic beauty. These results suggest that current and potential visitors perceive farms and forests as settings with the capacity to satisfy similar recreational needs especially related to excitement, learning experiences, and nostalgia.

In contrast, paired $t$ tests revealed statistically significant differences across the two agricultural settings on the importance of the remaining eight motivations. Specifically, respondents tended to place significantly greater importance on using their equipment $\left(M_{\text {forest }}=3.81\right.$;
$\left.M_{\text {farm }}=3.65\right)$, giving their mind a rest $\left(M_{\text {forest }}=3.79\right.$; $\left.M_{\text {farm }}=3.70\right)$, enjoying the smells and sounds of nature $\left(M_{\text {forest }}=4.13 ; M_{\text {farm }}=4.06\right)$, sharing their agritourism/ outdoor skills $\left(M_{\text {forest }}=3.33 ; M_{\text {farm }}=3.07\right)$, having a change from their daily routine $\left(M_{\text {forest }}=3.98\right.$; $\left.M_{\text {farm }}=3.90\right)$, and experiencing solitude $\left(M_{\text {forest }}=3.73\right.$; $\left.M_{\text {farm }}=3.57\right)$ in private forests settings when compared to farmlands. Conversely, doing something with the family $\left(M_{\text {farm }}=4.28 ; M_{\text {forest }}=4.12\right)$ and experiencing new and different things $\left(M_{\text {farm }}=3.98 ; M_{\text {forest }}=3.88\right)$ were more significantly important motivations for visiting farmlands relative to private forests.

These results suggest individuals expect distinctly different outcomes from their visits to either farmlands or private forests, which may be associated with the different images attached to these settings, while forests mainly portray notions of trees, farms are usually associated with fields and some farm animals. These results also suggest that both types of agricultural settings have competitive advantages their managers could capitalize on. For example, farm owners in the state interested in developing or expanding agritourism opportunities would be well advised, given these results, to emphasize the novelty (experiencing new and different things and experiencing excitement) that certain agritourism activities provide (e.g., hand-picking fresh produce or navigating a "haunted" corn 
maze). Similarly, data suggest that farm operators would be well served if they emphasized how visiting a farm for recreation can provide an opportunity to be with close friends and family (do something with their family and be with people having similar values).

\section{Conclusion}

Implications for Agritourism Planners and Managers

This study set out to explore the importance of different motivations to visit farmlands, private forests, or state and national parks in Missouri and to compare the importance of different motivations across the three setting types. Our intent was to discern if individuals desire different outcomes from recreational activities they pursue in different settings. The findings have key planning, management, and marketing implications. Our findings are especially relevant for agritourism businesses given the limited information available on this form of outdoor recreation in private settings as compared to public lands. Taking into consideration the emerging stage of agritourism in the USA, coupled with the economic burden that many small agricultural settings are going through, our conclusions elaborate more on the significance of the study results that are applicable to farms and private forests. However, we recognize that this study carries additional implications related to recreation on public lands.

At the business level, the importance of different motivations for outdoor recreation participation can help landowners plan and manage their agritourism endeavors within a customer-oriented philosophy. For example, study results suggest that farms involved in agritourism should include some type of recreational self-harvest activity (pick-your-own fruit or vegetable) because it was preferred by current and potential agritourists. Offering self-harvest activities and marketing them as novel (experience new and different things was rated significantly more important for farms relative to private forests) and family- and friendoriented activities (do something with family and be with people having similar values were higher for potential visits to farms relative to private forests) are especially important for those farm's owners who want to diversify their operations into the recreational sector at minimal costs. In addition, forest owners who want to attract visitors should ensure access for hiking, biking, or cross-country activities, as those were highly preferred activities among respondents. Also, given that doing something with their family was considered in both cases as one of the most important motivations, farm and forest landowners offering recreational opportunities should provide a variety of attractions to ensure an enjoyable experience for all family members, especially since family togetherness is a recurrent motivation in the literature (Kyle et al. 2006). Developing and managing recreation based on the needs and wants of current and potential agritourists can increase visitors' satisfaction levels, which in turn, can help to retain customers by encouraging repeat visitation, while capturing new visitors.

Study results can also serve to craft or re-direct marketing strategies of those farms/forests offering or willing to offer recreational services. Marketing is useful for competitive strategy and product positioning as it provides agritourism operators the ability to differentiate the products or experiences they offer from similar offerings by their competitors (Middleton et al. 2009). For example, study results suggest that farms should focus their advertisement around recreational self-harvest activities and events (e.g., festivals, shows), given these activities were the most preferred. Previous research also suggests that these activities are already two of the most commonly offered by Missouri's agritourism farms (Tew and Barbieri 2012). As another example, this study's findings suggest that private forests can compete with farms by advertising their settings as suitable for wildlife observation or to satisfy a unique set of needs (e.g., the use of equipment). Moreover, results suggest that private forests have the capacity to heavily position themselves as suitable settings for hiking, biking, crosscountry, wildlife observation, and fishing, all activities typically sought in state and national park settings (Cordell 2004, 2008). This is specifically important for non-industrial private forests in the Ozark Mountains of Missouri, which have already been recognized as recreation and leisure providers (Kurtz and Lewis 1981).

Similar findings regarding preferred activities and motivations between agricultural settings (farms and private forests) can be used by agencies and offices promoting agritourism development at the local, state, or regional level. For example, agritourism marketing and advertisement campaigns can be designed to attract those interested in spending some family time, while enjoying nature. Agencies can also use results on motivations to provide a better market-based guidance to those farm/forest landowners interested in agritourism. For example, they can guide landowners wishing to diversify their income by offering recreational activities dependent upon available resources, such as crops suitable for recreational self-harvest, extensive open spaces for festivals or events, or trails for hiking and biking.

Limitations, Theoretical Contributions and Recommendations for Future Research

Two limitations to the study warrant consideration. The first relates to the study's sample. The study's findings are only generalizable to residents of Missouri. Caution should 
be exercised when comparing this study's findings to other states or regions given that individuals' preferences and behaviors are usually influenced by geographic as well as socio-economic variables. In this case, it is important to take into consideration that Missouri has a unique geography influenced by the presence of the Lake of the Ozarks, conveniently located in the heart of the state which makes it easily accessible from anywhere. A second limitation is that this study only focused on a single psychological factor (motivations) known to influence behavior. Excluded were a variety of social (e.g., the availability of others to participate in activities with) and structural (e.g., the existence of nearby agritourism operations) factors that have been empirically linked to recreation participation (Wilhelm Stanis et al. 2009). Further research on motivations to visit agritourism settings would benefit by incorporating these other social psychological factors. Current understanding of agritourism motivations could be expanded by focusing on larger geographical contexts (e.g., multi-state level). It would also be useful to contrast localities with different levels of agritourism development (e.g., growing agritourism markets vs. better established ones) to examine whether few perceived differences between farms and forested lands fade or to the contrary, greater differences emerge.

Despite these limitations, and besides the aforementioned practical implications, this study has brought to light some important questions about how social scientists investigate motivations for recreation participation. The REP scales developed in the mid to late 1970s were designed primarily to tap into potential motivations for visiting publically managed nature-based areas such as primitive and semi-primitive areas within US National Forests and formally designated wilderness areas. Consequently, little attention was paid to desired outcomes that could be achieved from vising non-traditional recreation sites such as farms and private forests. For example, the initial REP scales do not contain items querying about "supporting local or small-scale businesses" or "learning about local agricultural products," which may applicable to motivations for participating in agritourism. Data revealed stronger motivations for visiting state and national or parks relative to farms and private forests; this result might be an artifact of the scale items' original purpose of elucidating motivations more typical to nature-based recreation areas. Future agritourism research might benefit from identifying recreation motivations that are specific to farms and private forests. Their development, and subsequent incorporation into the master list of REP statement items, would provide social scientists with a tool that could more accurately reflect dominant and growing forms of outdoor recreation.

This research also enhanced the scientific community's knowledge of agritourism. Although some studies define agritourism as visiting any working agricultural, horticultural, or agribusiness operation (Barbieri and Mahoney 2009; Che et al. 2005; Lobo 2001), most of the existing literature focuses on farms, with little information available on private forests. In this regard, the statistical differences in preferences and motivations between visitors to private forests and farms suggest that these types of settings should be included when examining agritourism.

Acknowledgments The authors express their gratitude to the University of Missouri Research Board for funding this project. Our thanks are also due to the journal editors and the reviewers for their thorough suggestions and comments.

\section{References}

Anderson DH, Fulton DC (2008) Experience preferences as mediators of the wildlife related recreation participation: place attachment relationship. Hum Dimens Wildl 13(2):73-88

Anderson DH, Wilhelm Stanis SA, Schneider IE, Leahy JE (2008) Proximate and distant visitors: differences in importance ratings of beneficial experiences. J Park Recreat Adm 26(4):47-65

Armstrong JS, Overton TS (1977) Estimating nonresponse bias in mail surveys. J Mark Res 14(3):396-402

Barbieri C, Mahoney E (2009) Why is diversification an attractive farm adjustment strategy? Insights from Texas farmers and ranchers. J Rural Stud 25(1):58-66

Barbieri C, Mshenga P (2008) The role of firm and owner characteristics on the performance of agritourism farms. Sociol Rural 48(2):166-183

Barbieri C, Mahoney E, Butler L (2008) Understanding the nature and extent of farm and ranch diversification in North America. Rural Sociol 73(2):205-229

Barry JJ, Hellerstein D (2004) Farm recreation. In: Outdoor Recreation for 21st Century America. A Report to the Nation: The National Survey on Recreation and the Environment. pp 149-167

Beh A, Bruyere B (2007) Segmentation by visitor motivation in three Kenyan national reserves. Tour Manag 28(6):1464-1471

Bernath K, Roschewitz A (2008) Recreational benefits of urban forests: explaining visitors' willingness to pay in the context of the theory of planned behavior. J Environ Manage 89(3):155-166

Butler BJ, Leatherberry EC (2004) America's family forest owners. J For 102(7):4-14

Che D, Veeck A, Veeck G (2005) Sustaining production and strengthening the agritourism product: linkages among Michigan agritourism destinations. Agric Hum Values 22(2):225-234

Chen H (2008) A study of yoga participants' leisure motivation, enduring involvement and benefits of leisure (Master thesis). Leader University, Taiwan

Clarke J (1999) Marketing structures for farm tourism: beyond the individual provider of rural tourism. J Sustain Tour 7:26-47

Cordell K (2004) Forest recreation. In: Outdoors Recreation for 21st Century America. A Report to the Nation: The National Survey on Recreation and the Environment. pp 141-148

Cordell K (2008) The latest on trends in nature-based outdoor recreation and tourism. Forest History Today Spring, Berlin, pp 4-10

Cordell K, Bergstrom J, Hartmann L, English D (1990) An analysis of the outdoor recreation and wilderness situation in the United States: 1989-2040. General Technical Report RM-189. U.S. Department of Agriculture, Forest Service, Rocky Mountain Forest and Range Experiment Station, Fort Collins, CO 
Daniel TC, Muhar A, Arnberger A, Aznar O, Boyd JW, Chan KMA, Costanza R, Elmqvist T, Flint CG, Gobster PG, Grêt-Regamey A, Lave R, Muhar S, Penker M, Ribe RG, Schauppenlehner T, Sikor T, Soloviy I, Spierenburg M, Taczanowska K, Tam J, von der Dunk A (2012) Contributions of cultural services to the ecosystem services agenda. Proc Natl Acad Sci 109(23): 8812-8819

Devesa M, Laguna M, Palacios A (2010) The role of motivation in visitor satisfaction: empirical evidence in rural tourism. Tour Manag 31(4):547-552

Dillman DA, Smyth JD, Christian LM (2009) Internet, mail, and mixed-mode surveys: the total design method, 3rd edn. Wiley, New York, p 499

Driver BL (1976) Quantification of outdoor recreationists' preferences. In: van der Smissen B (ed) Research on camping and environmental education. The Pennsylvania State University, State College, pp 165-188

Driver BL (1983) Master list of items for recreation experience preference scales and domains, Unpublished document, USDA Forest Service, Rocky Mountain Forest and Range Experiment Station, Fort Collins, CO

Driver BL (1996) Benefits-driven management of natural areas. Nat Areas J 16(2):94-99

Driver BL (2008) Managing to optimize the beneficial outcomes of recreation. Venture, State College

Geide C, Harmon L, Baker R (2008) Northern Virginia wineries: Understanding visitor motivations for market segmentation. In: Klenosky DB, Fisher CL (eds) Proceedings of the 2008 Northeastern Recreation Research Symposium; 2008 March 30-April 1; Bolton Landing, NY. Gen. Tech. Rep. NRS-P-42. U.S. Department of Agriculture, Forest Service, Northern Research Station, Newtown Square, PA, pp 350-356

Gil Arroyo C, Barbieri C, Rozier Rich S (2013) Defining agritourism: a comparative study of stakeholders' perceptions in Missouri and North Carolina. Tour Manag 37:39-47

Graefe A, Thapa B, Confer J, Absher J (2000) Relationships between trip motivations and selected variables among Allegheny National Forest visitors. USDA Forest Service Proceedings RMRS-P-15-VOL-4

Graefe DA, Schuster RM, Green GT, Cordell HK (2010) Management implications of changes in recreation activity motivation across physical settings. In: Watts CE, Fisher CL (eds) Proceedings for the 2009 Northeastern Recreation Research Symposium; 2009 March 29-31; Bolton Landing, NY. General Technical Report NRS-P-66. U.S. Department of Agriculture, Forest Service, Northern Research Station, Newtown Square, PA, pp 257-263

Gursoy D, Chi C, Dyer P (2010) Locals' attitudes toward mass and alternative tourism: the case of Sunshine Coast, Australia. J Travel Res 49(3):381-394

Hall T, Seekamp E, Cole D (2010) Do recreation motivations and wilderness involvement relate to support for wilderness management? A segmentation analysis. Leis Sci 32(2):109-124

Halpenny E (2006) Environmental behaviour, place attachment and park visitation: a case study of visitors to Point Pelee National Park (Master thesis). University of Waterloo, Waterloo

Howell DC (2013) Statistical methods for psychology, 8th edn. Wadsworth, Belmont

Huh C, Vogt C (2008) Changes in residents' attitudes toward tourism over time: a cohort analytical approach. J Travel Res 46(4):446-455

Ilbery B, Bowler I, Clark G, Crockett A, Shaw A (1998) Farm-based tourism as an alternative farm enterprise: a case study from the Northern Pennines, England. Reg Stud 32(4):355-364

Iso-Ahola SE (1999) Motivational foundations of leisure. In: Jackson EL, Burton TL (eds) Leisure studies: prospects for the twentyfirst century. Venture Publishing Inc., State College, pp 35-51
Jackson E (2005) Leisure constraints research: overview of a developing theme in leisure studies. In: Jackson EL (ed) Constraints to leisure. Venture, State College, pp 3-19

Jolly D, Reynolds K (2005) Consumer demand for agricultural and onfarm nature tourism. UC Small Farm Center Research Brief 2005-01. http://www.agri-toursolutions.com/pdf/agtourbrief013006.pdf. Accessed 10 June 2010

Karppinen H (1998) Values and objectives of non-industrial private forest owners in Finland. Silva Fennica 32(1):43-59

Kemperman A, Timmermans H (2006) Preferences, benefits, and park visits: a latent class segmentation analysis. Tour Anal 11(4):221-230

Kim H, Borges M, Chon J (2006) Impacts of environmental values on tourism motivation: the case of FICA, Brazil. Tourism Management 27(5):957-967

Kurtz W, Lewis B (1981) Decision-making framework for nonindustrial private forest owners: an application in the Missouri Ozarks. J For 79(5):285-288

Kyle G, Mowen A, Tarrant M (2004) Linking place preferences with place meaning: an examination of the relationship between place motivation and place attachment. J Environ Psychol 24(4):439-454

Kyle G, Absher J, Hammitt W, Cavin J (2006) An examination of the motivation-involvement relationship. Leis Sci 28(5):467-485

Lobo R (2001) Helpful agricultural tourism (agritourism) definitions. UC Small Farm Program. www.sfc.ucdavis.edu/agritourism/ definition.html. Accessed 25 January 2010

Luo Y, Deng J (2008) The new environmental paradigm and naturebased tourism motivation. J Travel Res 46(4):392-402

Manfredo MJ, Driver BL, Tarrant MA (1996) Measuring leisure motivation: a meta-analysis of the recreation experience preference scales. J Leis Res 28(3):188-213

Marques H (2006) Searching for complementarities between agriculture and tourism - the demarcated wine-producing regions of northern Portugal. Tour Econ 12:147-155

McCool S, Reilly M (1993) Benefits segmentation analysis of state park visitor setting preferences and behavior. J Park Recreat Adm 11(4):1-14

McEwen J (2010) Examining the interrelationship of motivation and place attachment in a residential 4-h camping environment. Master's thesis, Virginia Polytechnic Institute and State University, Blacksburg, VA

McGehee NG (2007) An agritourism systems model: a Weberian perspective. J Sustain Tour 15(2):111-124

McGehee NG, Kim K (2004) Motivation for agri-tourism entrepreneurship. J Travel Res 43(2):161-170

Middleton VTC, Fyall A, Morgan M (2009) Marketing in travel and tourism, 4th edn. Elsevier Ltd., Oxford, p 502

Newman DH, Wear DN (1993) Production economics of private forestry: a comparison of industrial and nonindustrial forest owners. Am J Agric Econ 75:674-684

Nickerson N, Black R, McCool S (2001) Agritourism: motivations behind farm/ranch business diversification. J Travel Res 40(1):19-26

Nilsson PA (2002) Staying on farms-An ideological background. Ann Tour Res 17(3):227-352

Ollenburg C, Buckley R (2007) Stated economic and social motivations of farm tourism operators. J Travel Res 45(4):444-452

Packer J, Ballantyne R (2002) Motivational factors and the visitor experience: a comparison of three sites. Curator Mus J 45(3): 183-198

Park D, Yoon Y (2009) Segmentation by motivation in rural tourism: a Korean case study. Tour Manag 30(1):99-108

Pierskalla CD, Lee ME, Stein TV, Anderson DH, Nickerson R (2004) Understanding relationships among recreation opportunities: a meta-analysis of nine studies. Leis Sci 26(2):163-180

Ritchie B, Tkaczynski A, Faulks P (2010) Understanding the motivation and travel behavior of cycle tourists using involvement profiles. J Travel Tour Mark 27(4):409-425 
Sharpley R, Sharpley J (1997) Rural tourism: an introduction. Thomson Business Press, London, p 165

Siderelis C, Moore RL, Yeung Y-F, Smith JW (2012) A nationwide production analysis of state park attendance in the United States. J Environ Manage 99:18-26

Smith J (2008) Utah off-highway vehicle owners' specialization and its relationship to environmental attitudes and motivations. Master thesis, Utah State University, Logan, UT

Smith WB, Miles PD, Vissage JS, Pugh SA (2003) Forest resources of the United States, 2002. General Technical Report NC-241. U.S. Dept. of Agriculture, Forest Service, North Central Research Station, St. Paul, MN

Stein T, Denny C, Pennisi L (2003) Using visitors' motivations to provide learning opportunities at waterbased recreation areas. J Sustain Tour 11(5):404-425

Teasley RJ, Bergstrom JC, Cordell HK, Zarnoch SJ, Gentle P (1999) Private lands and outdoor recreation in the United States. In: Cordell HK, Betz C, Bowker JM, English DBK, Mou SH, Bergstrom JC, Teasley RJ, Tarrant MA, Loomis J (eds) Outdoor recreation in American life: a national assessment of demand and supply trends. Sagamore Publishing, Champaign, pp 183-218

Tew C, Barbieri C (2012) The perceived benefits of agritourism: the provider's perspective. Tour Manag 33(1):215-224

Thapa B, Confer J, Mendelsohn J (2004) Trip motivations among water-based recreationists. Paper presentation at the 2nd International Conference on Monitoring and Management of Visitor Flows in Recreational and Protected Areas. Rovaniemi, Finland, pp 208-212

U.S. Census Bureau (2011) State \& county quick facts-Missouri. http://quickfacts.census.gov/qfd/states/29000.html. Accessed 23 March 2011

USDA Forest Service (2012) About Us. http://www.fs.fed.us/aboutus. Accessed 17 Jan 2012

USDA: ERS (2004) Measuring rurality: Rural-urban continuum codes. http://www.ers.usda.gov/briefing/rurality/ruralurbcon/. Accessed 9 Sept 2010
USDA: NASS (2009) 2007 Census of agriculture: United States Summary and State Data. Volume 1, Part 51. http://www.agcensus.usda.gov/ Publications/2007/Full_Report/index.asp. Accessed April 2011

Veeck G, Che D, Veeck J (2006) America's changing farmscape: a study of agricultural tourism in Michigan. Prof Geogr 50(3):235-248

Vogelsong H, Graefe A, Confer J, Solan D, Kramp J (1998) Relationships between motivations, activities and settings: the recreation opportunity spectrum within the Delaware state park system. In: Vogelsong HG, (comp, ed) Proceedings of the 1997 Northeastern Recreation Research Symposium; 1997 April 6-9; Bolton Landing, NY. Gen. Tech. Rep. NE-241. U.S. Department of Agriculture, Forest Service, Northeastern Forest Experiment Station, Radnor, PA, pp 124-127

Walker G, Deng J, Dieser R (2001) Ethnicity, acculturation, selfconstrual, and motivations for outdoor recreation. Leis Sci 23(4):263-283

Walls M, Darley S, Siikamäki J (2009) The state of the great outdoors: America's parks, public lands, and recreation resources. Resources for the Future. 1616 P Street, NW, Washington, DC 20036-1400. http://www.rff.org/RFF/Documents/RFF-RPT-ORRG-State-ofOutdoors.pdf. Accessed 25 Oct 2010

Weber D, Anderson DH (2010) Contact with nature: recreation experience preferences in Australian parks. Ann Leis Res 13(1-2):46-69

Wilhelm Stanis SA, Schneider IE, Anderson DH (2009) State park visitors' leisure time physical activity, constraints and negotiation strategies. J Park Recreat Adm 27(3):21-41

Yuan MS, McEwen D (1989) Test for campers' experience preference differences among three ROS setting classes. Leis Sci 11(3): $177-185$ 